\title{
Pengaruh Sikap Keuangan, Sosial, dan Pengetahuan Keuangan terhadap Perencanaan Keuangan Pribadi
}

\author{
Sonny Christian dan Hendra Wiyanto \\ Program Studi Manajemen Fakultas Ekonomi \& Bisnis \\ Universitas Tarumanagara \\ Email: sonnychristian45@yahoo.com
}

\begin{abstract}
This study aims to determine the effect of financial attitude, social influence, and financial knowledge to personal financial planning. Data collected by online questionnaire with sample technique judgement purposive sampling. Subject of this study is Millenial workers at Jakarta Barat. The result of this study is financial attitude, social influence, and financial knowledge has positive effect to personal financial planning. Hope next study can show another variables that have impact to personal financial planning.
\end{abstract}

Keywords: Financial Attitude, Social Influence, Financial Knowledge, Personal Financial Planning.

Abstrak : Tujuan dari penelitian ini yaitu untuk mengetahui pengaruh dari sikap keuangan, sosial, dan pengetahuan keuangan terhadap perencanaan keuangan pribadi. Pengumpulan data dilakukan dengan menggunakan kuesioner secara online yang disebarkan dengan pemilihan sampel judgement purposive sampling. Subjek dari penelitian yaitu kalangan milenial yang telah bekerja di Jakarta Barat. Hasil dari penelitian ini yaitu bahwa sikap keuangan, sosial, dan pengetahuan keuangan berpengaruh secara positif terhadap perencanaan keuangan pribadi. Diharapkan penelitian selanjutnya mampu menunjukkan variabel lain yang mampu memberi pengaruh terhadap perencanaan keuangan pribadi.

Kata Kunci: Sikap keuangan, pengaruh sosial, pengetahuan keuangan, perencanaan keuangan pribadi.

\section{LATAR BELAKANG}

Meningkatnya sikap konsumtif menjadi gejala dari sikap irasional seseorang. Sikap irasional ini dapat dilihat dari perilaku pengelolaan keuangan seseorang. Menurut Garman \& Irene (1996), kemungkinan kesalahan perilaku antara lain terlalu banyak pengeluaran, penggunaan kredit berlebihan, mencapai tagihan maksimum dalam kartu kredit, kehabisan uang, telat dalam membayar tagihan, tidak mampu membayar tagihan, tidak memiliki dana untuk kebutuhan tak terduga, dan 15 kesalahan perilaku lainnya.

Pengetahuan akan produk keuangan belum diketahui oleh sebagian besar masyarakat. Survei oleh Financial Inclusion Index (2014) menyatakan bahwa rata - rata tingkat kepemilikan rekening bank orang dewasa Indonesia hanya sebesar 36 persen, tertinggal dengan rata - rata negara Asia Tenggara lain dan global dengan besar persentase sebesar 62 persen. Survei dilakukan dengan wawancara kepada 150.000 orang dewasa yang tersebar lebih dari 140 negara. Pemanfaatan jasa keuangan untuk perencaan keuangan tergolong masih rendah dan belum mencapai target keuangan inklusif yang ditetapkan oleh Presiden Republik Indonesia Joko Widodo, yaitu sebesar 50 persen.

Kalangan milenial belum memprioritaskan perencanaan keuangan dari penghasilan yang diterima. Menurut survei oleh Charles Schwab dengan topik Modern Wealth Survey menyatakan bahwa kaum milenial tercatat sebagai responden yang paling banyak setuju 
terkait tingginya pengeluaran akibat media sosial dan menghabiskan waktu bersama teman. Selain itu, responden juga lebih memerhatikan pengeluaran teman dibanding simpanan yang dilakukan. Survei ini dilakukan dengan total 1.000 responden dengan kaum milenial $(23-38$ tahun) sebesar 380 responden. Kuesioner tersebar kepada berbagai ras dengan proporsional pria dan wanita sebanyak 49 persen dan 51 persen.

Oleh sebab itu, peneliti berminat untuk meneliti "Pengaruh sikap keuangan, sosial, dan pengetahuan keuangan terhadap kalangan milenial yang telah bekerja di Jakarta Barat".

\section{KAJIAN TEORI}

Penelitian ini mengacu pada Theory of Planned Behavior (TPB) oleh Ajzen (Lange et $a l ., 2012)$ dengan tujuan untuk untuk mengetahui tingkah laku seseorang dengan menambah faktor baru yang memengaruhi intensi perilaku seseorang dari teori sebelumnya, yaitu tingkat pengendalian. Tujuan penambahan variabel perceived control yaitu untuk mengetahui keterbatasan individu dalam menjalankan suatu perilaku. Ada 3 faktor yang memengaruhi intensi perilaku seseorang :

Attitude toward behavior, terkait dengan kombinasi keyakinan perilaku dan evaluasi hasil untuk menghasilkan penilaian positif atau negatif. Subjective norm, terkait dengan keyakinan normatif mengenai referensi sosial yang menghasilkan tekanan sosial yang dirasakan. Perceived control, terkait dengan keyakinan diri untuk mampu melakukan suatu perilaku jika merasa sanggup dilakukan.

Hubungan Antara Sikap Keuangan dan Perencanaan Keuangan Pribadi. Sikap keuangan mampu memengaruhi perencanaan keuangan pribadi dilihat dari suatu pola keuangan yang terbentuk akibat dari sikap keuangan seseorang. Sikap keuangan menjadi respon evaluatif terhadap perilaku keuangan (Xiao et al., 2011; Dalam jurnal Spolter et al., 2017). Tingkat prioritas akan pentingnya perencanaan keuangan pribadi akan mendorong seseorang untuk memiliki perencanaan keuangan pribadi yang lebih baik. Hipotesis awal peneliti yaitu sikap keuangan berpengaruh secara positif terhadap perencanaan keuangan pribadi, didukung dengan hasil penelitian jurnal Spolter et al., dan Murphy \& Yetmar.

Dari teori-teori diatas, maka dapat dirumuskan hipotesisnya adalah sebagai berikut: H1: Sikap keuangan berpengaruh secara positif terhadap perencanaan keuangan pribadi

Hubungan Antara Pengaruh Sosial dan Perencanaan Keuangan Pribadi. Pengaruh sosial mampu memengaruhi perencanaan keuangan pribadi seseorang akibat adanya tekanan dalam memutuskan suatu tindakan. Shim et al. (2010; dalam jurnal Jamal et al., 2015) menyatakan bahwa sosialisasi orang tua lebih berperan secara signifikan terhadap perilaku keuangan anak yang beranjak dewasa dibandingkan dengan pengalaman kerja dan edukasi finansial. Selain itu, Duflo \& Saez (2001) menemukan bahwa orang - orang yang tergabung dalam sebuah kelompok dengan similaritas yang tinggi, membentuk hubungan antara perilaku kelompok dengan perilaku individu. Peneliti merumuskan hipotesis awal bahwa pengaruh sosial berpengaruh secara positif terhadap perencanaan keuangan pribadi yang didukung dengan hasil penelitian jurnal jamal et al.

Dari teori-teori diatas, maka dapat dirumuskan hipotesisnya adalah sebagai berikut:

$\mathrm{H} 2$ : Pengaruh sosial berpengaruh secara positif terhadap perencanaan keuangan pribadi 
Hubungan Antara Pengetahuan Keuangan dan Perencanaan Keuangan Pribadi. Pengetahuan keuangan subjektif dan objektif mampu memengaruhi perencanaan keuangan pribadi melalui kepercayaan diri melakukan perencanaan keuangan pribadi. Xiao et al. (2011; dalam jurnal Spolter et al., 2017) menyatakan bahwa seseorang dengan pengetahuan kartu kredit yang baik akan mampu mengontrol risiko dari pengeluaran menggunakan kartu kredit. Berdasarkan hasil temuan diatas, pengetahuan keuangan mampu memberikan kemampuan pengendalian dalam merencanakan keuangan. Dari temuan ini peneliti merumuskan hipotesis awal bahwa pengetahuan keuangan berpengaruh secara positif terhadap perencanaan keuangan pribadi, didukung dengan hasil penelitian dalam jurnal Spolter et al.

Dari teori-teori diatas, maka dapat dirumuskan hipotesisnya adalah sebagai berikut:

H3: Pengetahuan keuangan berpengaruh secara positif terhadap perencanaan keuangan pribadi

\section{METODOLOGI}

Jenis desain penelitian yang digunakan dalam penelitian ini adalah penelitian deskriptif. Sekaran \& Bougie (2017) menjelaskan bahwa tujuan dari penelitian deskriptif adalah untuk memperoleh data yang mendeskripsikan ketertarikan dari suatu topik. Penelitian deskriptif dirancang untuk memperoleh data yang mampu menjelaskan karakteristik dari suatu objek (orang, organisasi, produk, atau merk). Penelitian ini dirancang untuk mengetahui bagaimana karakteristik seseorang dalam mengambil keputusan terkait perencanaan keuangan pribadi yang dipengaruhi oleh variabel yang dibatasi, terdiri atas sikap keuangan, pengaruh sosial dan pengetahuan keuangan.

Peneliti menggunakan teknik nonprobability sampling dalam penelitian ini karena peneliti menentukan sendiri populasi yang menurut pertimbangan pribadi peneliti mampu mewakili pemecahan masalah berdasarkan solusi atas hasil pengolahan data dari penelitian, yaitu kalangan milenial yang telah bekerja. Jenis nonprobability sampling yang digunakan dalam penelitian yaitu judgement purposive sampling. Dalam jenis penelitian ini, sampel dipilih berdasarkan pertimbangan peneliti dengan penyesuaian terhadap tujuan dan masalah dalam penelitian. Peneliti merasa bahwa sampel yang dipilih mampu memberikan informasi yang tepat dan benar untuk penelitian. Kriteria untuk pemilihan subjek penelitian ditujukan kepada kalangan milenial yang telah bekerja. Pemilihan kalangan milenial yang telah bekerja sebagai sampel penelitian disesuaikan dengan masalah yang dihadapi, yaitu prioritas kalangan milenial dalam bekerja untuk memperoleh pendapatan yang maksimal dan kurangnya kesadaran kalangan milenial akan pentingnya perencanaan keuangan pribadi.

Skala pengukuran yang digunakan untuk keseluruhan variabel dalam penelitian yaitu skala Ordinal. Teknik pengukuran data ordinal yang digunakan adalah skala Likert. Skala Likert dirancang untuk menguji berapa besar subjek setuju atau tidak setuju terhadap pernyataan. Skala likert yang digunakan yaitu 5 kategori, dari sangat tidak setuju, tidak setuju, netral, setuju, dan sangat setuju.

Jumlah indikator yang digunakan untuk mengukur sikap keuangan yaitu 3 indikator. Indikator variabel sikap keuangan terdiri dari sikap kognitif, sikap afektif, dan sikap konatif. Jumlah indikator yang digunakan untuk mengukur pengaruh sosial yaitu 2 indikator. Indikator variabel pengaruh sosial terdiri dari sosialisasi orang tua dan pengaruh teman sebaya Jumlah indikator yang digunakan untuk mengukur pengetahuan keuangan yaitu 2 indikator. Indikator variabel pengetahuan keuangan terdiri dari pengetahuan subjektif dan pengetahuan objektif. Jumlah indikator yang digunakan untuk mengukur perencanaan keuangan pribadi yaitu 6 indikator. Indikator variabel perencanaan keuangan pribadi terdiri 
dari perencanaan pajak, perencanaan arus kas, investasi, manajemen risiko, perencanaan pensiun dan perencanaan properti.

Pada penelitian ini menggunakan model structural equation modelling atau SEM. Dimana, dalam SEM ini terdiri atas 2 model yaitu outer model yang terdiri atas uji validitas dan reliabilitas dan inner model. Analisis validitas dengan menggunakan SEM yaitu analisis convergent validity. Sedangkan dalam uji inner model yang digunakan dalam penelitian ini adalah: uji koefisien determinasi (R square), uji Cross Validated Redundancy $\left(\mathrm{Q}^{2}\right)$, dan uji hipotesis.

\section{HASIL ANALISIS DATA}

Penelitian dilakukan dengan melibatkan 76 responden dimana data diperoleh menggunakan metode kuesioner. Kuesioner disebar sejak pertengahan November hingga pertengahan Desember 2019. Responden yang memenuhi kriteria karakteristik dalam penelitian, yaitu kalangan milenial yang telah bekerja di Jakarta Barat sebanyak 55 responden.

Karakteristik demogafi dalam penelitian ini melibatkan kategori jenis kelamin, pendapatan per bulan, pendidikan, status, dan jumlah anak. Untuk kategori jenis kelamin diperoleh jumlah yang seimbang setiap karakteristik, yaitu 27 pria dan 28 wanita. Untuk kategori pendapatan per bulan, karakteristik yang dominan dari responden yang diperoleh yaitu pendapatan dibawah Rp.10.000.000 per bulan sebanyak 39 responden. Untuk kategori pendidikan, karakteristik yang dominan dari responden yang diperoleh yaitu responden dengan tingkat pendidikan S1 sebanyak 40 responden. Untuk kategori status, karakteristik yang dominan dari responden yang diperoleh yaitu responden dengan status belum menikah sebanyak 49 responden. Untuk kategori jumlah anak, karakteristik yang dominan dari responden yang diperoleh yaitu responden yang belum memiliki anak sebanyak 51 responden.

Average Variance Extracted (AVE) yang diterima dalam validitas penelitian, yaitu melebihi 0,5. Nilai AVE dari setiap variabel memiliki nilai lebih dari 0,5 sehingga memenuhi ketentuan validitas konvergen dalam penelitian.

Tabel 1. Hasil Analisis Average Variance Extracted

\begin{tabular}{|l|c|}
\hline \multicolumn{1}{|c|}{ Variabel } & Nilai AVE \\
\hline Sikap keuangan & 0,734 \\
\hline Pengaruh sosial & 0,789 \\
\hline Pengetahuan keuangan & 0,783 \\
\hline Perencanaan keuangan pribadi & 0,605 \\
\hline
\end{tabular}

Uji validitas dilakukan dengan membandingkan hasil olah data dengan nilai standar Outer Loadings yang diterima dalam penelitian, yaitu 0,70. Nilai Outer Loadings dari setiap variabel memiliki nilai lebih dari 0,70 sehingga memenuhi ketentuan validitas konvergen dalam penelitian.

Tabel 2. Hasil Analisis Outer Loadings

\begin{tabular}{|l|c|c|}
\hline Variabel & Indikator & Nilai Outer Loadings \\
\hline \multirow{3}{*}{ Sikap keuangan } & FA1 & 0,825 \\
\cline { 2 - 3 } & FA2 & 0,865 \\
\cline { 2 - 3 } & FA3 & 0,880 \\
\hline \multirow{2}{*}{ Pengaruh sosial } & SI1 & 0,918 \\
\cline { 2 - 3 } & SI2 & 0,858 \\
\hline
\end{tabular}


Sonny dan Hendra : Pengaruh Sikap Keuangan, Sosial, dan Pengetahuan...

\begin{tabular}{|l|c|c|}
\hline Pengetahuan keuangan & FK1 & 0,911 \\
\cline { 2 - 3 } & FK2 & 0,858 \\
\hline \multirow{4}{*}{ Perencanaan keuangan pribadi } & PFP1 & 0,805 \\
\cline { 2 - 3 } & PFP2 & 0,799 \\
\cline { 2 - 3 } & PFP3 & 0,792 \\
\cline { 2 - 3 } & PFP4 & 0,768 \\
\cline { 2 - 3 } & PFP5 & 0,777 \\
\cline { 2 - 3 } & PFP6 & 0,721 \\
\hline
\end{tabular}

Uji reliabilitas dilakukan dengan membandingkan hasil pengolahan data dengan standar nilai Cronbach Alpha yang diterima dalam reliabilitas penelitian, yaitu diatas 0,7. Nilai Cronbach Alpha dari setiap variabel memiliki nilai lebih dari 0,7 sehingga memenuhi ketentuan reliabilitas dalam penelitian.

Tabel 3. Hasil Analisis Cronbach Alpha

\begin{tabular}{|l|c|}
\hline \multicolumn{1}{|c|}{ Variabel } & Nilai Cronbach Alpha \\
\hline Sikap keuangan & 0,819 \\
\hline Pengaruh sosial & 0,737 \\
\hline Pengetahuan keuangan & 0,726 \\
\hline Perencanaan keuangan pribadi & 0,869 \\
\hline
\end{tabular}

Nilai $R$ Square menunjukkan pengaruh variabel independen secara keseluruhan terhadap variabel dependen. Dalam penelitian ini, $R$ Square yang dihasilkan yaitu sebesar 0,618. Hasil ini menunjukkan bahwa sikap keuangan, pengaruh sosial, dan pengetahuan keuangan memiliki pengaruh terhadap perencanaan keuangan pribadi sebesar $61,8 \%$.

\begin{tabular}{|c|} 
Tabel 4. Nilai $R$ Square \\
\hline Nilai $R$ Square \\
\hline 0,618 \\
\hline
\end{tabular}

$\mathrm{Q}^{2}$ dalam penelitian dilihat berdasarkan hasil olah data pada software SmartPLS. Hasil $\mathrm{Q}^{2}$ diperoleh dengan kalkulasi blindfolding pada SmartPLS. Berdasarkan hasil olah data, nilai $\mathrm{Q}^{2}$ yang diperoleh dalam penelitian ini yaitu 0,304 . Hasil tersebut melambangkan bahwa variabel perencanaan keuangan pribadi memiliki prediktif relevansi dalam model penelitian dikarenakan nilai $\mathrm{Q}^{2}$ yang dihasilkan lebih dari 0 .

\begin{tabular}{|c|}
\hline Tabel 5. Nilai $\mathrm{Q}^{2}$ \\
\hline Nilai $\mathrm{Q}^{2}$ \\
\hline 0,304 \\
\hline
\end{tabular}

$P$ Values menunjukkan apakah variabel independen memiliki pengaruh secara signifikan terhadap variabel dependen. Standar yang perlu dipenuhi dalam penelitian yaitu dibawah 0,05 untuk $P$ Values masing - masing variabel. Hal ini menunjukkan semua variabel independen yang terdiri dari sikap keuangan, pengaruh sosial, dan pengetahuan keuangan memiliki pengaruh secara signifikan terhadap variabel dependen dalam penelitian, yaitu perencanaan keuangan pribadi.

Tabel 6. Nilai $P$ Values Penelitian

\begin{tabular}{|l|c|}
\hline \multicolumn{1}{|c|}{ Variabel } & Nilai $P$ Values \\
\hline Sikap keuangan & 0,000 \\
\hline Pengaruh sosial & 0,048 \\
\hline
\end{tabular}


Sonny dan Hendra : Pengaruh Sikap Keuangan, Sosial, dan Pengetahuan...

\begin{tabular}{|l|r}
\hline Pengetahuan keuangan & 0,032 \\
\hline
\end{tabular}

Untuk melihat besarnya pengaruh dan hubungan antara variabel independen dengan variabel dependen dilihat pada nilai original sample estimate dalam tabel path coefficient yang dihasilkan dari pengolahan model SEM dengan cara bootstrapping pada aplikasi SmartPLS. Hasil original sample estimate dalam penelitian ini yaitu diatas 0 dan positif sehingga semua variabel independen memiliki pengaruh positif terhadap variabel dependen. Hal ini menandakan bahwa semua hipotesis awal peneliti yang menyatakan semua variabel independen memiliki pengaruh positif terhadap variabel dependen dapat diterima.

Tabel 7. Nilai Original Sample Estimate

\begin{tabular}{|l|c|}
\hline \multicolumn{1}{|c|}{ Variabel independen } & Nilai Original Sample Estimate \\
\hline Sikap keuangan & 0,542 \\
\hline Pengaruh sosial & 0,225 \\
\hline Pengetahuan keuangan & 0,266 \\
\hline
\end{tabular}

Hasil pengujian hipotesis dalam penelitian ini yang dimulai dengan hipotesis awal yang dibentuk peneliti yaitu bahwa sikap keuangan berpengaruh secara positif terhadap perencanaan keuangan pribadi $\left(\mathrm{H}_{1}\right)$ dapat diterima. Hal ini dibuktikan dengan hasil olah data $P$ Values sikap keuangan terbukti memiliki pengaruh terhadap perencanaan keuangan pribadi melebihi standar yang ditetapkan, yaitu dibawah 0,05. Nilai original sample estimate yang diperoleh juga melebihi 0 dan positif, yaitu 0,542. Sikap keuangan menjadi hal yang perlu dievaluasi seseorang jika orang tersebut telah menyadari bahwa ia belum merencanakan keuangan pribadi.

Hipotesis awal peneliti yang berikut yaitu pengaruh sosial berpengaruh secara positif terhadap perencanaan keuangan pribadi $\left(\mathrm{H}_{2}\right)$ juga dapat diterima. Hal ini dibuktikan dengan hasil olah data $P$ Values pengaruh sosial terbukti memiliki pengaruh terhadap perencanaan keuangan pribadi melebihi standar yang ditetapkan, yaitu dibawah 0,05 . Nilai original sample estimate yang diperoleh juga melebihi 0 dan positif, yaitu 0,225. Perencanaan keuangan pribadi yang baik mampu dilakukan seseorang jika ia berada di lingkungan sosial yang mendukung, baik keluarga maupun teman.

Hipotesis awal peneliti yang ketiga, yaitu pengetahuan keuangan berpengaruh secara positif terhadap perencanaan keuangan pribadi $\left(\mathrm{H}_{3}\right)$ juga dapat diterima. Hipotesis awal peneliti dapat diterima karena nilai $P$ Values dalam penelitian memenuhi nilai yang ditetapkan. Hubungan positif antara variabel independen dengan variabel dependen juga sesuai dengan hipotesis awal peneliti yang dapat dilihat dari nilai Original Sample Estimate yang dihasilkan dari penelitian diatas 0 dan positif, yaitu 0,266 . Hal ini menunjukkan bahwa seseorang perlu memiliki pengetahuan keuangan yang memadai jika ingin merencanakan keuangan pribadi dengan baik.

\section{DISKUSI}

Berdasarkan hasil diatas, maka dapat dikatan bahwa penelian ini sudah valid dan reliabel karena telah lolos dari semua pengujian yang ada. Pengujian dimulai dari uji validitas dan reliabilitas, diikuti dengan uji inner model yang terdiri dari $R$ square, $\mathrm{Q}^{2}, P$ Values, $T$ Statistic, dan Original Sample Estimate.

Hasil ini sesuai dengan hasil penelitian yang tercantum dalam daftar pustaka penulis. Dimulai dari Xiao et al., (2011; Dalam jurnal Spolter et al., 2017) yang menyatakan bahwa Sikap keuangan menjadi respon evaluatif terhadap perilaku keuangan. Selain itu hasil penelitian juga didukung Shim et al. (2010; dalam jurnal Jamal et al., 2015) menyatakan bahwa sosialisasi orang tua lebih berperan secara signifikan terhadap perilaku keuangan anak 
yang beranjak dewasa dibandingkan dengan pengalaman kerja dan edukasi finansial. Selanjutnya . Xiao et al. (2011; dalam jurnal Spolter et al., 2017) juga menyatakan bahwa seseorang dengan pengetahuan kartu kredit yang baik akan mampu mengontrol risiko dari pengeluaran menggunakan kartu kredit.

\section{KESIMPULAN}

Berdasarkan pada hasil analisis dan pembahasan pada Bab IV, maka dapat disimpulkan sebagai berikut:

1. Sikap keuangan berpengaruh positif terhadap perencanaan keuangan pribadi pada kalangan milenial yang telah bekerja di Jakarta Barat.

2. Pengaruh sosial berpengaruh psotif terhadap perencanaan keuangan pribadi pada kalangan milenial yang telah bekerja di Jakarta Barat.

3. Pengetahuan keuangan berpengaruh positif terhadap perencanaan keuangan pribadi pada kalangan milenial yang telah bekerja di Jakarta Barat.

\section{SARAN}

Peneliti menyarankan Kalangan milenial yang telah bekerja di Jakarta Barat mampu lebih memahami pentingnya perencanaan keuangan pribadi dan variabel - variabel yang memengaruhinya setelah membaca penelitian ini. Dalam kelanjutannya, peneliti berharap kalangan milenial yang telah bekerja di Jakarta Barat mampu untuk merencanakan keuangan pribadi masing - masing dengan lebih baik dengan mengetahui apa saja yang mampu memengaruhi perencanaan keuangan pribadi dan melihat lebih detail faktor - faktor yang ada di dalamnya. Peneliti juga menyarankan bagi pengembang ilmu untuk mampu mengembangkan penelitian lebih lanjut dengan jumlah sampel yang lebih besar dan lebih lengkap. Dalam penelitian ini, peneliti hanya mampu menjelaskan 61,8\% variabel yang memenaruhi perencanaan keuangan pribadi. Diharapkan pengembang ilmu mampu menjelaskan lebih banyak variabel yang memengaruhi perencanaan keuangan pribadi sehingga hasil penelitian menjadi lebih mendetail dan mampu lebih menjelaskan variabel dependen tersebut.

\section{DAFTAR RUJUKAN/PUSTAKA}

Altfest, L. (2004). Personal Financial Planning : Origins, Developments, and a Plan for Future Direction. American Economist, 48(2), 53 - 60.

Asosiasi Fintech Indonesia (2017) Persentase Fintech Indonesia Menurut Sektor Usaha (Retrieved from https://databoks.katadata.co.id/)

Charles Schwab (2019) Modern Wealth Survey (Retrieved from www.schwab.com)

Deloitte Touche (2019) The Deloitte Global Milennial Survey (Retrieved from https://databoks.katadata.co.id/)

Eddy S.W. Ng \& Johnson, J. M. G. (2015). Millennials: who are they, how are they different, and why should we care?. (6), $121-137$.

Ferdinand, A. (2014). Metode Penelitian Manajemen Pedoman Penelitian untuk Penulisan Skripsi Tesis dan Disertasi Ilmu Manajemen. Semarang : Badan Penerbit Universitas Diponegoro.

Filbert, R. (2016). Passive Income Strategy The Secret of Financial Freedom. Jakarta : PT Elex Media Komputindo.

Garman, E. T., Leech, I. E. \& Grable, J. E. (1996). The Negative Impact Of Employee Poor Personal Financial Behaviors On Employers. Financial Counseling and Planning Volume 7. 
Sonny dan Hendra : Pengaruh Sikap Keuangan, Sosial, dan Pengetahuan...

Global Findex (2014) Financial Inclusion Index (Retrieved from https://databoks.katadata.co.id/)

Guzman, F. \& Paswan, A. (2019). Consumer Centric Antecedents to Personal Financial Planning. Journal of Consumer Marketing, 36(6), 858 - 868.

Hair, J. F., Sarstedt, M., Hopkins, L. \& Kuppelwieser, V. G. (2014). Partial least squares structural equation modeling (PLS-SEM) An emerging tool in business research. European Business Review. 26(2).

Halim \& Ishak. (2014). Post Election Behavior? Is it Possible? A Framework Based on Hirschman (1970) Model. Journal of basic and applied sciences. 8(12), 67-75.

Jamal, A. A. A., Ramlan, W. K., Karim, M. R. A., Mohidin, R. \& Osman, Z.(2015). The Effects of Social Influence and Financial Literacy on Savings Behavior: A Study on Students of Higher Learning Institutions in Kota Kinabalu, Sabah. International Journal of Business and Social Science, 6(1), 110 - 119.

Jorgensen, B. L. \& Savla, J. (2010). Financial Literacy of Young Adults : The Importance of Parental Socialization. Journlal of Family Relations, 59(4), 465 - 478.

Lai, M. M. \& Tan, W. K. (2009). An Empirical Analysis of Personal Financial Planning in an Emerging Economy. European Journal of Economics, Finance and Administrative Sciences, 16, $99-111$.

Lange, P. A. M., Kruglanski, A.W. \& Higgins, E. T. (2012).The Theory of Planned Behavior.Handbook of theories of social psychology. 1, 438-459.

Mahapatra, M. S., Raveendran, J., \& De, A. (2016). Proposing the Role of Mental Accounting and Financial Cognition on Personal Financial Planning: A Study in Indian Context. Journal of Economic Policy \& Research, 12(1), 62 - 73.

Murphy, D. S. \& Yetmar, S. (2010). Personal Financial Planning Attitudes: A Preliminary Study of Graduate Students. Management Research Review, 33(8), 811 - 817.

Robb, A. C. \& Woodyard, A. S. (2011). Financial Knowledge and Best Practice Behavior. Journal of Financial Counseling and Planning, 22(1), 60 - 70.

Santoso, E. (2016). 15 Tips Jitu Mencapai Financial Freedom. Jakarta : Grasindo.

Sekaran, M. \& Bougie, R. (2017). Research Methods for Business : A Skill Building Approach Seventh Edition. United Kingdom : John Wiley \& Sons Ltd.

Simoes, L. \& Gouveia, L. B. (2008). Targeting the Millennial Generation. Journal of Public and Communication, 21, 1- 10.

Spolter, S. W., Fiona, S., Rippe, C. \& Gould, S. (2017). Integrating Affect, Cognition, and Culture in Hispanic Financial Planning. International Journal of Bank Marketing, 36(4), $726-743$.

Statista (2017) Transaksi Fintech Indonesia (Retrieved from https://databoks.katadata.co.id/)

Syaputra, I. D. (2018). Perkembangan dan Pengaruh Digital Financial Services sebagai Keuangan Inklusif terhadap Consumer Spending di Indonesia tahun 2015 - 2017. Disertasi. Universitas Indonesia, Depok.

Wang, A. (2009). Interplay of Investors' Financial Knowledge and Risk Taking. The Journal of Behavioral Finance, 10, $204-213$.

Widoatmodjo, S. (2015). Pengetahuan Pasar Modal untuk Konteks Indonesia. Jakarta : PT Elex Media Komputindo. 